despite the prominence given to this field by today's media.

Barcelona's city council commissioned this beautifully produced guidebook to fill the gap between its artistic heritage and the less well known scientific and technological tradition. The citizens have a significant appreciation of scientists, and not just those associated with their city. Street names remind us of Pasteur, Archimedes, Descartes and Fleming, for example, and the hall in the Industrial School has walls covered with engravings commemorating scientists from all over the world and from many different disciplines. There is even a monument to the city's direct role in determining the standard metre. The French definition of this distance was one ten-millionth of a quadrant of the Earth on the longitudinal line passing through Paris; as part of this project, Jean Delambre and Pierre Méchain were assigned the task of measuring precisely the distance between Dunkirk and Barcelona.

This guidebook is divided into two major parts: the first describes the scientific and technological history of the city, and the second comprises suggested itineraries through the various geographical areas. There are also four excellent maps, as well as a multitude of colour illustrations. The book is so wide-ranging that it provides something for everyone. Outdoor types can use it as a guide when they view remnants of the old Roman aqueduct and a short stretch of canal that carried water to the city for several hundred years. A stroll along Notariat Street leads to the house occupied by the Nobel-prizewinning neurologist Santiago Ramón y Cajal during his tenure at the University of Barcelona. Botanical gardens of all sizes abound.

For the more traditional traveller there are museums dedicated to geology, ethnography, medical instrumentation, pharmacology and many varied types of technological applications. And when all this science begins to be a bit much, there is the Picasso Museum and the Museum of Catalan Art, both of which are highly praised by the ubiquitous Michelin Green Guide. Here one can enjoy not only the visual pleasures on display but also an entertaining discussion in this book about the relationship between the arts and science.

We have never been to Barcelona, but reviewing Walks Around the Scientific World of Barcelona has led us to consider making the trip from North Yorkshire to this marvellous city. The one caveat is that the book's excellent production quality has led to it being a somewhat weighty tome, difficult for those of us no longer in the bloom of youth to carry on our sightseeing tours.

Jacqueline Reynolds and Charles Tanford are authors of The Scientific Traveller: A Guide to the People, Places and Institutions of Europe (Wiley, 1992).

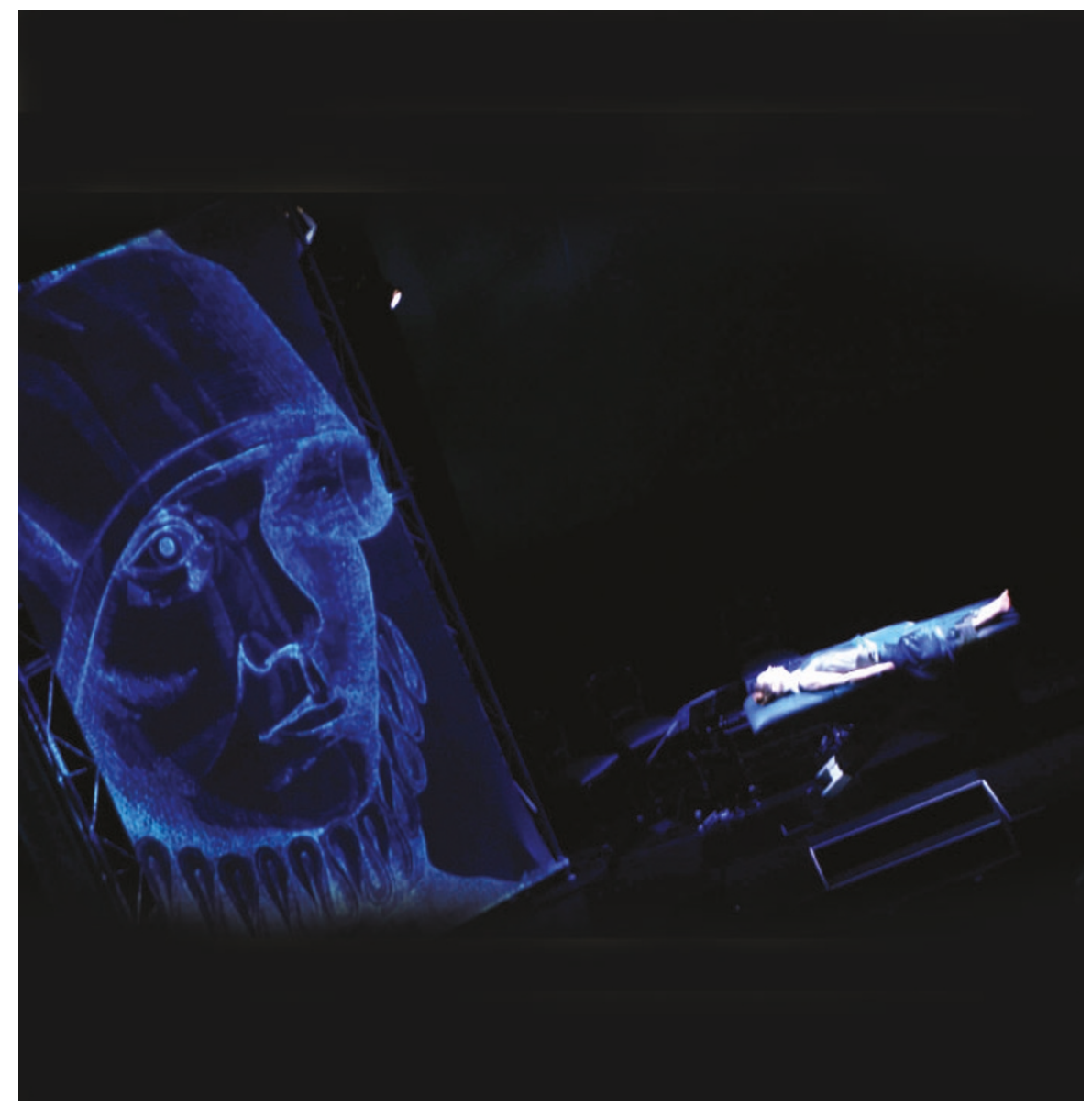

Up close and personal: images on giant screens oversee a virtual anatomy lesson in Tulp, the Body Public.

Performance

\section{A visceral \\ experience}

\section{Tulp, the Body Public \\ www.elision.org.au/projects/tulp}

\section{Carina Dennis}

An anatomy lesson delivered over the flayed arm of an executed thief is the inspiration behind Justine Cooper's Tulp, the Body Public, an intimate and confrontational performance event that explores the theme of medical surveillance of the human body.

An Australian currently living in New York, Cooper weaves together a video collage of vox-pop narratives with fragments of baroque opera and contemporary music composed by John Rodgers and performed by ELISION, an Australian new-music ensemble. Tulp premiered last month at the Sydney Festival and will be performed at the Brisbane Festival on 23-25 September 2004.

Cooper collected anecdotes from members of the general public from a booth at the Art Gallery of New South Wales during the month before the performance. As a vehicle to intimacy, the volunteers had vascular ultrasound Doppler recordings taken, before being interviewed about their attitudes to medicine, pain, life and death.

Close-up camera angles of volunteers faces as they tell their stories capture some visceral experiences: one man's attempt at home surgery using insufficient anaesthetic, a woman's recovery from breast cancer, the torture of treatment for scoliosis, and a grandmother's experiences as a surrogate mother.

The 60-minute multimedia performance, - inspired by Rembrandt's painting The Anatomy Lesson of Dr Nicolaes Tulp - draws on baroque imagery, which is projected onto two giant latex screens on either side of the centre stage. The soft gurgling of the vascular ultrasound recordings is an audio backdrop to the contemporary compositions, periodically interrupted by improvisations in which the musicians 'dissect' their instruments - by analogy with medical interventions. The audio and visual stimulation is overwhelming at times, even to the point of distraction.

The audience is simultaneously watching and being watched. The soprano, who provides a link between the narrative and the music, carries a wireless camera strapped to her wrist. She sometimes directs it at the audience, projecting their images onto the central screen.

Carina Dennis is Nature's Australasian correspondent. 